The Fournal of Modern African Studies, 37, 4 ( I 999), pp. 7 I I-722

Printed in the United Kingdom (C) I 999 Cambridge University Press

\title{
A reply to Pitcher
}

\author{
Christopher Cramer and Nicola Pontara*
}

Pitcher's rejoinder to our paper (Cramer \& Pontara I998), is a useful contribution to the policy and analytical debate on poverty and rural relations in Mozambique. Some of her points are well taken, in particular her careful attention to empirical imprecision in much of the literature. Indeed, she points out that we used a figure for how much land the government had conceded to private owners that turns out to be mistaken. We accept this useful clarification graciously, though slightly less graciously would point out that Pitcher earlier cited the same (erroneous) figure herself. ${ }^{1}$

Overall, her complaint about our paper seems to boil down to the following: that we are incomplete in our coverage of the literature; that we fail to notice that the government may say it favours smallholders but is in fact leaving them high and dry by allocating resources to largescale commercial investors; and that we present an exclusive choice between the land and the labour market as the solution to poverty in Mozambique. On the first point, our coverage was indeed less than complete, though the implications of this are not as Pitcher implies. On the second, we think the picture is more complex than she suggests, and if our paper did not make this adequately clear we shall try to make it more so here. On the third part of her complaint, Pitcher is plainly wrong: in fact, the most interesting thing about her comment on our paper is that she appears entirely to have missed the point that we were making and does not engage with our core argument at all. She is at pains to agree with our discussion of the socioeconomic differentiation that has a long-term and more recent history in rural Mozambique, and to present the lives of the poor as highly insecure. Nonetheless, she makes little effort to consider the implications of this beyond making the fairly obvious point that people hang onto their land when they can and pursue multiple and 'redundant' (whatever this is supposed to mean) strategies.

* Christopher Cramer is at the School of Oriental and African Studies, London. Nicola Pontara is currently working within the Ministry of Planning and Finance in Maputo, as an ODI Fellow: any views expressed here are personal and do not express those of the Ministry or the government. We were deeply sorry to hear of the tragic death of Scott Kloeck-Jenson, resident director of the Land Tenure Centre in Maputo, during the preparation of this comment in June I999. 
DOMINANT THEMES IN THE LITERATURE

Pitcher is uncomfortable with what in her view we erroneously define as the 'official literature'. She argues that we engage in selective reading and ignore other contributions that share some of the characteristics of the sources we surveyed. Furthermore, we are charged with misinterpreting the position of the Ministry of Agriculture/Michigan State University (MOA/MSU) collaboration on the role of joint-venture companies (JVCs) in rural Mozambique. Contrary to our view, she argues that MOA/MSU repeatedly recognised the potentially progressive role of JVCs. She goes on to say that even though the articles we discuss all emanate from the various government ministries, they are not necessarily representative of official government policy regarding agrarian development. In fact, many of the current government initiatives in rural areas, notably land concessions and the formation of joint ventures with big national and international firms, are antithetical to the objective of a homogeneous peasantry stabilised on the land. She concludes: 'At the very least, these actions suggest that the government has multiple, contradictory and conflicting "official" policy positions on what to do with the peasantry.' There is certainly truth in this.

Our main aim was to select some influential literature on poverty and poverty alleviation policy in Mozambique, which also expressed the dominant view $(\mathrm{s})$ of the government. It is for this reason that the authors referred to the contributions surveyed as the 'official literature'. The ig95 Poverty Alleviation Strategies for Mozambique and I996 Rural Poverty Profile, for instance, were the only substantial documents focusing on (rural) poverty on a national scale to be produced by government sources between the early i 990 os and i $998 .^{2}$ Furthermore, it is undeniable that the contribution of Myers and of Myers and West has profoundly influenced the debate on agrarian issues in Mozambique. It perpetuated the dualist conception of a traditional subsistence-oriented homogeneous peasantry standing in opposition to large-scale commercial enterprises. And it created a suggestive image of land-insecure smallholders displaced by large commercial enterprises and 'land grabbers', making a dent in the conscience of many contributors to the debate. These points cannot be emphasised enough. As Kloek-Jenson (1998) puts it:

a variety of authors and practitioners have tended to pit an undifferentiated smallholder sector against avaricious economic and political elites whose 
acquisition of land necessarily impinges on the interests of the former. Myers concluded that smallholders were squeezed out as large landholdings were being parcelled out to 'new and returning private national and foreign enterprises' and 'government officials'.

As will be argued below, these images are still alive among those actively involved in 'land issues' in Mozambique. Pitcher also notes the existence of other documents that share the characteristics of those we surveyed. However, she cites only two additional sources in footnote 2. It is far from clear that the literature we discussed represents simply an irrelevant 'straw' argument.

According to Pitcher, our focus on one article produced by the MOA/MSU cooperation neglects other contributions where MOA/ MSU has underlined the potential progressive role of JVGs. Nonetheless, the document in question has been by far the most influential amongst those produced by this partnership. Tschirley and Weber ( I 994: I 70) do indeed state that "cotton growing enterprises may offer one way out of the quandary ... by generating significant amounts of cash income... (through both cotton sales and work in cotton processing plants)...'. However, their policy suggestions epitomise much of MOA/MSU policy stances. They in fact conclude by saying that 'the size and quality of land will remain very important in determining the welfare of most rural households... and thus...improving the technological and management packages available to smallholders to increase food and cash crops yields is of key importance...' (ibid: I 7 I). They do not present any serious policy consideration of the scope for public policy to influence the progressive potential of large-scale commercial agricultural enterprises or contract farming or outgrower schemes, for example through influencing cropping patterns, exerting leverage over agribusinesses with respect to labour issues, or influencing the labour market access and conditions of women via education and anti-discrimination policies. Given the political and economic realities of rural Mozambique, we argue strongly that the 'progressive potential' of various forms of agribusiness and, indeed, smaller-scale capitalist farming enterprise, needs to attract greater analytical, empirical and policy attention, not least because this potential is unlikely to be maximised by relying on 'trickle-down' mechanisms.

The next question refers to whether or not these contributions reflect the government policy position of 'what to do with the peasantry'. It is perhaps useful at this stage to distinguish land tenure policy from agrarian development policy although the two are obviously interlinked.

First, it seems undeniable that the government attaches great 
importance to secure access to land for the Mozambican peasantry. As Frelimo's five-year plan (GOM i 995: 84-34, underline added) puts it:

Land is one of the most important and precious national resources... The government will reinforce mechanisms that will ensure its use and exploitation/improvement through the following actions:

- Intensification of the process of land distribution, particularly to the family sector and small producers, guaranteeing at the same time the issuing of land titles for land use and exploitation;

- Promotion of a better circulation of the Land Law and its regulations.

Some commentators, including Pitcher, seem to doubt the willingness of the government to carry out this commitment in practice. As she puts it

it is equally the case that many current initiatives are antithetical to that goal [i.e. the idea of a homogenous peasantry stabilised on the land]... The Mozambican government is conceding land to national and local government officials, and former Portuguese settlers. It is also forming joint ventures with some of the largest national and international companies....

However, in the last few years significant efforts have been undertaken to improve land security for both 'local communities' and private investors. The new Land Law was approved on 3 I July i 997, and makes an important step towards establishing a more transparent process through which land use rights can be acquired and maintained. ${ }^{3}$ According to Kloeck-Jenson ( I 998: 2), the Law 'provides a potential safeguard for rural smallholders by being more explicit than the old law in granting land use rights through occupancy as well as by requiring local communities" "participation" in the formal land titling process'. The effectiveness of the law will obviously depend on the capacity and willingness of the government to implement it and enforce it, along with the accompanying regulations. However, the pressure is mounting on Frelimo to comply with the implementation of the Law. Local NGOs, such as União Nacional das Associações dos Camponeses (UNAG) and Organizaçao Rural de Ajuda Mutua (ORAM), together with various international NGOs, the Land Tenure Centre and other institutions have been campaigning for the devolution of meaningful authority to the 'local community' and for the dissemination of the new Land Law regulations. LTG sources maintain that 'smallholders' are fairly secure on the land in today's Mozambique (personal communication i 999).

Second, the strategy for future agrarian development is expounded in the National Programme for Agrarian Development (PROAGRI). The programme was approved by the Council of Ministries in I998 
and is under way. It recognises belatedly the importance of boosting commercial agriculture. Nonetheless, the development of the so-called 'family sector' still plays an important role within PROAGRI. The document is based on three overall strategies. While Strategy I is concerned with Institutional Reforms, the overarching objective of Strategy 2 is to 'increase the levels of production and productivity in the agricultural sector... in order to increase the income of rural families and their levels of food security, preventing the degradation of natural resources' (PROAGRI, Documento Mestre I998: 42). The related list of activities includes, inter alia, the establishment of a number of input provision services (e.g. technology transfers, extension services, quality seeds provision, etc.) for the benefit of the 'family sector'. Furthermore, Strategy 3 aims at 'protecting, preserving, developing and guaranteeing the access of the population to natural resources... with a view to utilise them rationally and in a sustainable way ...' (ibid. I 998: 42). The formulation and implementation of the Land Law figures as one of the strategy's related activities.

The development of the 'family sector' is also central to the new official anti-poverty agricultural agenda. The Action Plan for the Eradication of Absolute Poverty, approved in April i 999, assumes that 9o per cent of rural peasants obtain their income from subsistence agriculture. It stresses the need to increase agricultural productivity notably for very small cultivators, through extension activities, the introduction of low-cost technology, artisan irrigation systems, animal traction, seeds and access to credit (GOM I999:22).

In the light of this evidence, and despite the very real contradictions within policymaking and between words and practice, it is not sensible to continue to portray 'smallholders' or the 'family sector' as the victims, wholesale, of a conspiracy between the government and big national and multinational interests. Indeed, precisely in recognising the different strands of agrarian policy we argue that the capitalist and/or agribusiness sector must be a central feature of realistic analysis and policy debates. This is all the more so since, first, there are likely limitations to the success of family sector-based strategies and, second, there is a need to distinguish between the average rural household collected under the rubric of the family sector and the poorest rural households and individuals. The poorest, thanks to the problems of analytical categorisation in much empirical survey work, are frankly likely to be excluded from the benefits of both the Land Law and broader agrarian policies. 
'EITHER/OR'... OR 'BOTH/AND'?

In claiming that we present rural poverty alleviation 'as a choice between either land or wage labour', Pitcher blatantly misinterprets our argument. We are aware that rural households depend on a variety of income sources and pursue multiple livelihood strategies. We also recognise that land is often a crucial asset for the survival of the Mozambican population, although notably so for the average and better off (rural) households. Ironically, this point emerges clearly from Pitcher's (I998: I38, emphasis added) own analysis of agrarian relations in selected districts of Nampula. Thus:

In Monapo, the disparities between rich and poor households are dramatic. Out of 33 households surveyed the upper decile control one-third of the total land area. Moreover, the large landowners all hired labour and transported their cotton harvest to the market by tractor and truck. Their material possessions were also greater in number than that of the average household. All had radios, bicycles, chairs, beds, cooking utensils and plastic buckets. ${ }^{5}$

Pitcher's work in Nampula illustrates the level of household economic stratification. Very small cultivators and near-landless chronically deficit households coexist with small cultivators who can produce for subsistence and for the market, and medium to big cultivators who are likely to produce a sizeable surplus and can respond to market stimuli. The exchange processes and the land, labour and credit market involvement of these participants are neither uniform nor equal. The livelihood strategies that they pursue in order to survive are also likely to be different. Yet, Pitcher exclusively focuses on the livelihood strategies of the average and better-off households. ${ }^{6}$

There is nothing inherently wrong in focusing on this particular subset of households. However, our aim was precisely to focus on the livelihood strategies of those poor rural dwellers who throughout Mozambique increasingly depend on off-own farm income in general, and on poorly developed and segmented rural labour markets in particular. The case study carried out by the authors was obviously illustrative and presented in order to make the point. The point was made to try to add a dimension of the debate that we felt was inadequately dealt with in most of the dominant literature, not somehow to argue that the choice for all rural Mozambique was either land or wage labour. And the point was made to suggest that this is an area that requires far more research. It was also suggested tentatively that many rural women belonging to female-predominant households 
might be engaged in these types of activities, which often involve mobility (rural-rural migration).

These activities and the people who carry them out, however, continue to be 'invisible' in Mozambique. They are often excluded from 'statistically representative' surveys, as in the case of the recently completed UPM document (see footnote 2). They are largely ignored by Pitcher's I 998 article. They certainly receive an extraordinarily low proportion of the attention that is constantly paid to the so-called 'smallholders' or 'family sector' in Mozambique, not only in the academic literature but also amongst government 'anti-poverty' units, NGOs, the mass media and the public. This 'invisibility' has adverse consequences for their survival: no attention is paid to the extremely low wages they receive and to the working conditions they face. The implication of our analysis was that 'land security', per se, would not make a great deal of difference to these individuals, because they often lack access to labour and cash to cultivate land productively. On the contrary, it was suggested that alternative strategies, such as the development of wage labour opportunities in rural areas, could contribute to alleviate the poverty of many rural Mozambicans. Our argument does not depend on the actual hectarage conceded to large agribusinesses, but on (a) a recognition of the rich dynamics of differentiated ownership of and access to the means of production in rural Mozambique, including but not exclusively focusing on the latest reincarnation of large agribusiness in parts of the country, and (b) a purposive identification of the implications of differentiation and change by focusing on those rural poor people who, we have suggested, tend to be invisible in large-scale, so-called representative surveys.

\section{ENGLOSING THE TERMS OF DEBATE}

In her section on 'redundant strategies' and voices of protest, Pitcher closes the circle, returning to a romantic plea for the smallholder household living under insecurity and pining for the security of land. In so doing, she closes out the argument that the poverty debate in Mozambique needs to focus on the implications of the fact that many of the very poorest do and will continue to depend on access to very low-wage, casual or temporary employment opportunities. She refers to the "voices of protest emerging from the countryside against the land requests and allocations'. Echoing Myers, she goes on to say that 'within areas that have been irrigated... rich as well as poor smallholders have been shunted aside as others have moved in, waving 
their newly purchased titles'. She asserts that 'the conflicts over land are not invented; they are rooted in complaints about the fairness and the transparency of current allocation procedures', and that 'the desire for land is historically grounded in a perennial insecurity about economic survival as well as dynamic cultural interpretations about the symbolic meaning of land'. In order to substantiate her claim, she provides some examples of 'redundant, overlapping economic strategies' that rural households pursue in order to 'spread the risk of uncertainty'.

However, Pitcher does not cite evidence to support her claims. She merely makes vague reference to groups of deslocados living in the periurban areas of Maputo, Beira, Quelimane and Nampula and 'other towns'. We agree that the reality of differentiation and change in rural Mozambique is often conflictual, as it is anywhere. We agree, too, that people in insecure rural circumstances do seek land security and, indeed, that for some in the family sector - where there is sufficient good land, but also, critically, where access to complementary inputs is widespread and where productive and transport infrastructure provision are strong enough not to make the costs of such access and of marketing output prohibitive - then land is a valuable component of rural development and anti-poverty strategies. However, as we have highlighted, too relentless a focus on 'smallholder' land tenure security continues to divert attention from extremely pressing poverty issues.

Furthermore, in order to illustrate the importance of land for rural people, Pitcher continues to refer to the better-off rural households, to those who 'market cash crops ... to rural traders or companies' or 'sell animals and distilled alcohol to purchase bicycles and radios'. But these are precisely those households that are more likely to benefit from the revised Land Law and current agrarian policies in Mozambiquethough only in so far as these policies do improve infrastructure provision and input costs, which they will not do quickly in many parts of the country. What about those for whom promised land is unlikely to materialise in an escape from indigence?

\section{ADDING TO THE DEBATE}

Far too much attention is currently paid to the security of tenure of socalled smallholders in Mozambique, at the expense of focusing on those who, increasingly we suggest, are surviving on the basis of earnings from outside own-farm activities. These include people without land as well as those with varying degrees of secure access to land but with little 
access to complementary inputs. The current emphasis on land, moreover, tends to divert the attention from other crucial elements of Mozambique's poverty reduction strategy, such as the expansion of educational opportunities (notably for females) and the rehabilitation of, and need to expand, rural infrastructures that lower costs of production and exchange.

Although a number of authors have challenged the perception of rural Mozambique as being populated by a class of homogeneous smallholders crucially dependent on land and emphasised their level of social differentiation (O'Laughlin I996; Cramer \& Pontara I998; Pitcher I999), this image is still alive amongst some development practitioners. It has been argued, for instance, that the new Land Law has been based on this erroneous conceptualisation of rural areas. As Kloeck-Jenson (I998: 5) puts it, the reliance on 'simple and undifferentiated images of community, smallholders, or largeholders have produced critical strategic advantages in macro-political debate and struggles'. The implementation of the Law, however, will have now to face the complexity of ill-defined 'local communities' and the struggles that will take place therein. A brief example may illustrate this point. In order to protect 'peasant farmers', the new law recognises the legitimacy of 'customary' alongside the 'formal' land tenure system. However, given that 'customary norms' are thought to disadvantage women by denying them control over land, the law also states that women have equal land rights to men, thereby setting up an unresolved contradiction (Waterhouse i999). According to Waterhouse, the attempt at 'empowering' women through the setting up of legislation in favour of women's land rights is based on the fallacious assumption of a homogeneous smallholder sector, grouped in 'local communities', and on the dubious premise that 'customary norms and practices' are static. On the contrary, women in Ndixe, Southern Mozambique have managed in the post-war period to assert some control over land and extend the locus of ideal 'customary norm'. In short, the gains made by Ndixe women in terms of their control over land can be reversed by the new Land Law, in that the law leaves open a conservative interpretation of 'customary norms'. As Waterhouse (I 999: 2) points out: '(the) land reform process, explicitly meant to include rural women, may only marginally improve women's land tenure security. Furthermore, this is unlikely to contribute to increasing the agricultural output or reducing the poverty or rural women in Southern Mozambique.'

The debate on land is thus shifting the focus from 'smallholders' to 
'local communities' while presenting the same weaknesses. This shift may reflect the global emphasis on decentralisation and the desirability of 'community-based' management schemes (Kloeck-Jenson I998). Politically correct terms such as 'empowerment', 'voice', 'participation' (notably of women) are no longer confined to NGO personnel but are beginning to reach more orthodox institutions, such as the World Bank. ${ }^{7}$ These terms, however, merely constitute the façade that often masks vague analyses of the characteristics of the poor.

Meanwhile, near-landless peasants are beginning to emerge in rural Mozambique, while patterns of land accumulation continue to advance. A study conducted in Cabo Delgado documents the existence of significant groups of land-poor households in northern Mozambique. It also points to land inequality throughout the country (Francisco de Marrule I998). Furthermore, significant land concessions have been given to large agricultural enterprises. Foreign investors have undertaken substantial investments in the sugar sector (Mauritians in Zambezia, South Africans in Maputo Province). And foreign farmers, notably South Africans, are increasingly settling in Mozambique, either privately under land leasing arrangements, or through government schemes, such as the Mosagrius scheme launched in 1996 in the province of Niassa. Finally, a class of medium to big national farmers is also developing, especially in and around cash crop producing areas.

The most important implication of recent developments is that the importance of off-own-farm income, including agricultural wage labour, is increasing throughout rural areas. In her case study of Ndixe, Waterhouse (I999: 2 I) points to the existence of an increasing number of people, men and women, who depend on a variety of off-farm activities. She also reports that several women hire out their labour, although as a last resort strategy. A substantial number of female and male wage labourers are found, for example, on Lomaco's cotton fields around Chòkwé. This is also the case on Lomaco's fields in the district of Montepuez, Cabo Delgado, where thousands of labourers, including children, find seasonal employment of Lomaco's fields, including migrant wage labourers from as far as I oo $\mathrm{km}$ away (migrant labourers from Nanjua stay on the margins of Lomaco fields in huge huts for a period of two weeks at the time - fieldwork, i 998). According to local sources in Nacuca, Motepuez District, a market for seasonal and casual wage labourers is developing on the fields of more affluent 'smallholders', whose cotton production has substantially increased in the past five years. Big cotton companies like Lomaco are progressively 
scaling down direct cultivation and switching to the more profitable smallholder outgrower schemes. ${ }^{8}$ Fieldwork confirms that these schemes contribute to enhance social differentiation in rural areas in that conditions of entry, location, landholding size and access to productive inputs are far from uniform.

Whatever the scope for poverty reduction via secure landholding for some proportion of the members of the 'family sector', it is extremely important to acknowledge the significance in the lives of the poorest rural Mozambicans of off-farm income sources and, particularly, of opportunities and conditions in the agricultural wage labour market. Pitcher's comment on our paper makes some very useful points but basically perpetuates the neglect of these crucial issues. We sought not to turn one excessive simplification over to reveal another, equally simplistic, 'either/or' analysis, but to provoke more direct debate, research and analysis of those aspects of the complex relations of rural Mozambique that affect the poorest and that have received too little attention.

\section{NOTES}

I. The 40 million ha. figure is also cited in a footnote by Kloeck-Jenson (I998: 4) and by Pitcher (I999: fn. 7). Our recent efforts to clarify this issue have confirmed that the 'true' hectarage concerned is highly elusive, though by the estimates of most it is vaguely in the millions. 2. In I 998, the former Department of Population and Social Development (DPDS), ex-PAU, located within the Ministry of Planning and Finance produced Understanding Poverty in Mozambique: the First National Assessment (UPM i 998), in collaboration with the International Food Policy Research Centre (IFPRI). This document was based on the elaboration of the data collected by the National Institute of Statistics (INE) during the i 996/ 7 National Household Survey on Living Standard (IAF). DPDS is now called the Section for Sectoral Studies. Note also that the Rural Poverty Profile summarises the results of a number of studies carried out between I 990 and I 995 . 3. According to Waterhouse ( I 999: 22), the stated aims of Frelimo's National Land Policy of I 995, Revised Land Law of I 997 and Land regulation of i 998, are to guarantee social justice, promote agricultural development and guarantee food security.

4. The overall target of the various activities listed under this strategy is to reach nearly I million peasants.

5. Note that the two top landowners surveyed by Pitcher in Nampula had I6.5 and I $2 \cdot 5$ hectares respectively.

6. Despite the evidence she provides Pitcher ( I998: I 36) pays little attention to agricultural labourers and goes on to state that "only some households "hired" labour in exchange for food and/or drink and several households reported working for others in exchange for goods such as food, drink, and clothes'.

7. For a critique of the blithe invocation of this 'inclusive' rhetoric by NGOs, see, for example, Vivian \& Maseko (I994); and for a critique of the same tendency within recent World Bank literature, Sender (i 999).

8. Lomaco have different arrangements with cotton producers. Generally, the company offers credit for the purchase of inputs at the beginning of the season and then discounts these costs at harvest when smallholders sell their produce to the company (fieldwork I998). The debate over the socioeconomic implications of contract and outgrower farming schemes is ongoing and to date has yielded mixed conclusions: for an overview of some of the issues see, for example, Glover \& Kusterer ( I 990), Jackson \& Cheater ( I 994), and Porter \& Phillips-Howard (I 997). 


\section{REFERENGES}

Cramer, C. \& N. Pontara. I998. 'Rural poverty and poverty alleviation in Mozambique: what's missing from the debate?', Journal of Modern African Studies 36, г : г I-38.

Francisco de Marrule, H. I 998. " "Land-poor" in a "land-abundant" setting: unravelling a paradox in Mozambique', Relatório de Pesquisa (M.Sc. Plan B Paper MSU). Maputo: Ministério de Agricultura e Pesca (MAP).

Glover, D. \& K. Kusterer. I990. Small Farmers, Big Business: contract farming and rural development. London: Macmillan.

Government of Mozambique (GOM). 1995. 'Programa Quinquenal do Governo 1995-1999', Boletim da Republica, 40 Suplement, series I, I8, 84(22)-84(43).

GOM i999. Linhas de Erradicação da Pobreza Absoluta. Maputo: República de Moçambique, Conselho de Ministros.

Jackson, J. C. \& A. P. Cheater. I 994. 'Contract farming in Zimbabwe: case studies of sugar, tea and cotton', in P. D. Little \& M. Watts, eds., Living Under Contract. Madison: University of Wisconsin Press.

Kloeck-Jenson, S. 1997. Analysis of the Parliamentary Debate and the New National Land Law for Mozambique. Maputo: Land Tenure Centre.

Kloeck-Jenson, S. I 998. Locating the Community: local communities and the administration of land and other natural resources in Mozambique. Maputo: Land Tenure Centre.

O'Laughlin, B. 1996. 'Through a divided glass: dualism, class and the agrarian question in Mozambique', The Fournal of Peasant Studies 23, 4 .

PAU (Poverty Alleviation Unit). 1995. The Poverty Reduction Strategy for Mozambique. Maputo: Ministry of Planning and Finance.

PAU. I996. Rural Poverty Profile. Maputo: Ministry of Planning and Finance.

Pitcher, A. 1998. 'Disruption without transformation: agrarian relations and livelihoods in Nampula Province, Mozambique 1975-1995', Fournal of Southern African Studies 24, I : i i 7-42.

Pitcher, A. I 999. 'What's missing from "What's missing"? A Reply to C. Cramer and N. Pontara, "Rural poverty and poverty alleviation in Mozambique: what's missing from the debate?", Journal of Modern African Studies 37, 4.

Porter, G. \& K. Phillips-Howard. I 997. 'Comparing contracts: an evaluation of contract farming schemes in Africa', World Development 25, 2: 227-38.

Sender, J. I999. 'Re-assessing the role of the World Bank in Sub-Saharan Africa', paper for 'Reinventing the World Bank: Challenges and Opportunities for the $2 \mathrm{I}^{\text {st }}$ Century' conference, Northwestern University, I4-I6 May.

Tschirley, D. \& M. T. Weber. I994. 'Food security under extremely adverse conditions: the determinants of household income and consumption in rural Mozambique', World Development 22, 2: $159-73$.

UPM. 1998. Understanding Poverty in Mozambique: The First National Assessment. Maputo: Ministry of Planning and Finance in collaboration with IFPRI.

Vivian, J. \& G. Maseko. I994. 'NGOs, participation and rural development: testing the assumptions with evidence from Zimbabwe', Discussion Paper 49. Geneva: United Nations Research Institute for Social Development (UNRISD).

Waterhouse, R. I 999. 'Gender relations and land tenure: co-operation and conflict in Marracuene District, Southern Mozambique'. Mimeo. 